\title{
NOTES AND NEWS
}

one left about here, except the one near by which has had a new roof put on-at least it is new outside."

In Majorca similar huts are built to-day by the peasants. Near the bay of San Vicente a tabular limestone is worked and the construction of a hut is no difficult matter. The slabs of stone lend themselves easily to corbelling and this method is adopted for making the roof. Longer slabs form lintels above doors and windows.

\section{RHODESIA}

It is satisfactory to hear that the Rhodesian Public Works Department is showing an interest in the great ruins of which Zimbabwe is the most famous. Mr J. F. Schofield, a professional architect, has examined and reported on the two series of buildings known as the "Elliptical Temple' and the 'Acropolis.' This account, which is carefully and critically written, is published in a series of articles in the Rhodesia Herald, beginning 22 January 1926 . Being a trained and impartial man $\mathrm{Mr}$ Schofield arrives at the only possible conclusions as to date and origin, which are the same that I propounded twenty years ago. That is to say, the ruins are not earlier than the late Middle Ages and are to be ascribed to Bantu peoples. Fresh evidence, all tending the same way, has lately been adduced by Mr Douslin and the Rev. S. S. Dornan.

$\mathrm{Mr}$ Schofield's articles should be read by all who do not feel that the main issues have been finally settled, as well as those who have accepted the general scientific verdict but are interested in the details. It may be hoped that his records mark the opening of a new period in the study of southern Rhodesian antiquities. These are most important and valuable for the history of civilization; and South Africans ought to regard them as part of the history of their country, in the same way that the Americans have for many years devoted themselves to the study of the Indians before and after Columbus.

In the Fournal of the African Society Captain E. A. Norton writes a too brief article on ruins in the neighbourhood of Inyanga. These seem to be part of the same system, and perhaps part of the same site which I attempted to describe in my account of the ' Niekerk Ruins 'the second and third chapters of my book Mediaeval Rhodesia, which Captain Norton appears not to have read. There are endless terraces (built no doubt mainly for cultivation and not for defence as I had at first thought), and quite elaborate dwellings ; also some forts and a well defined road. These ruins lie in a remote and little-visited area, but 


\section{ANTIQUITY}

they have not wholly escaped attention. They are worthy of careful study and the official archaeologists should turn their energies upon them. That they are the work of a Bantu race is quite certain but their antiquity is perhaps a little greater than the 'experts' gave Captain Norton to believe ; I think they are probably a century or two earlier than Zimbabwe.

Mr R. S. Fairbridge, of Umtali, who has an unequalled knowledge of his own district, has written some articles to prove that the "slavepits' were used as tombs, or rather as cenotaphs. The theory is ingenious and deserves examination, but I prefer to regard these curious structures as habitations. Though simpler they are of the same generic class as the dwellings on the Niekerk site.

RANDAll MacIver.

\section{WINDMILL HILL, WILTSHIRE}

The greatest interest has been aroused in archaeological circles by the remarkable discoveries on Windmill Hill, near Avebury. Here the owners, Mr and Mrs Keiller, have been carrying out excavations for two seasons, with the assistance of Mr St. George Gray. The site was inhabited at a very early date in the prehistoric period; and the triple concentric ditches there, broken as they are by frequent causeways, have analogies in the Middle Rhine region. Mr Keiller allows the following forecast of his plans to be published. In 1927 digging will be carried out between 26 April and 28 May. Visitors will be allowed to visit the excavations on Saturday afternoons. The following year will be devoted to tabulating the results of the past three years' work, and to writing the first volume of the published account of the excavations. It is proposed to continue this method of publication every three or four years, and full arrangements have been made for the work to be carried on in the event of the death of any of the principals or any of the permanent staff. It is proposed thoroughly to excavate the entire site and any adjacent ground which might tend to throw light upon that site; but a certain portion of each distinctive part of the site will be left unexcavated and provision will be made for leaving these portions unexcavated for at least one century. Mr Keiller continues:- " This unusual arrangement is prompted by my realization of the inestimable advantage that it would have been to us of these days, had earlier excavators pursued this policy ; since it is merely futile to assume that future generations will not have further comparative data upon which to work, which will enable them doubtless to obtain more information from the excavation of a site than lies 